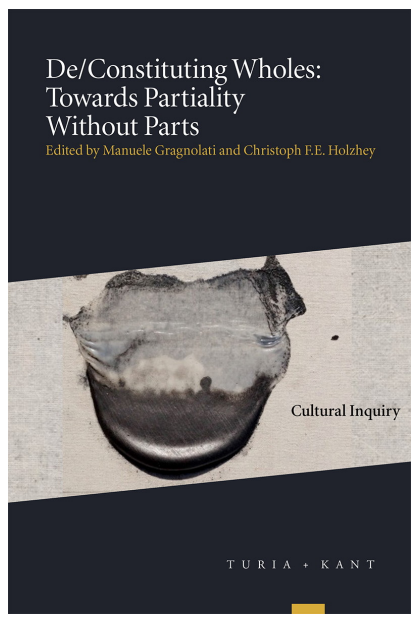

De/Constituting Wholes: Towards Partiality Without Parts, ed. by Christoph F. E. Holzhey and Manuele Gragnolati, Cultural Inquiry, 11 (Vienna: Turia + Kant, 2017), pp. 67-84

\section{EIRINI AVRAMOPOULOU \\ Claims of Existence between Biopolitics and Thanatopolitics}

CITE AS:

Eirini Avramopoulou, 'Claims of Existence between Biopolitics and Thanatopolitics', in De/Constituting Wholes: Towards Partiality Without Parts, ed. by Christoph F. E. Holzhey and Manuele Gragnolati, Cultural Inquiry, 11 (Vienna: Turia + Kant, 2017), pp. 67-84 <https://doi.org/10.37050/ci-11_04>

RIGHTS STATEMENT:

(C) by the author(s)

This version is licensed under a Creative Commons AttributionShareAlike 4.0 International License. 


\title{
CLAIMS OF EXISTENCE BETWEEN BIOPOLITICS AND THANATOPOLITICS
}

Eirini Avramopoulou*

\author{
Quickening. \\ They have to be written to the quick, on the now, \\ Live, \\ All these scenes, all these events which only happen once $[\ldots]$. \\ If you do not grab them in the instant they pass, these pulsa- \\ tions are lost forever. \\ Hélène Cixous, Stigmata (1998)
}

\section{QUICKENING}

From the balcony of a building overlooking Istiklal Street in Istanbul, Ali was joyfully waving to the massive crowd of people below marching and chanting in Turkish, Kurdish, Arabic, and Armenian slogans such as 'Don't be silent, shout out loud, there are homosexuals', 'Homophobic state', 'Sexist Erdoğan', 'If oppression and violence are moral, we are immoral.' Through each of these slogans reverberated the long history of the queer struggle to claim the public sphere, as well as more recent political developments amongst different activist groups and individuals who had met for the first time at the previous weeks' occupation of Gezi Park and were now present at the Pride March in solidarity with LGBT people.

Parts of this article have already been published in Eirini Avramopoulou, 'On the Fantasy of Dispossession', Cultural Anthropology, Special Issue: Hot Spots: An Impromptu Uprising: Ethnographic Reflections on the Gezi Park Protests in Turkey ed. by Yael Navaro-Yashin and Umut Yildirim (2013) <http://www. culanth.org/fieldsights/400-on-the-fantasy-of-dispossession> [accessed 10 January 2016]. Different versions of this article have been presented at the panel 'Hauntings' of the workshop De-Constituting Wholes, ICI Berlin Institute for Cultural Inquiry; at the conference Radical Negativity: Interrogating Productive Possibilities for Negative States of Being, Goldsmiths, University of London; and at the workshop TOPIKA ILT, Tinos island, Greece. I would like to warmly thank the organizers and participants at these venues for their valuable comments. This article is dedicated to Ali, whose life, energy, and smile will always accompany me. 
'This has never happened before; what is happening here is amazing' was Ali's comment when we met later in the street. What was amazing was that in 2013 an unprecedented 40,000 protestors turned this day into a historical event in the long fight against homophobia and sexism. Ten years earlier, only thirty people had come to support the first Pride event held in Istanbul, and a few years after that the numbers had reached only a few thousand.

In the summer of 2013, the echoes of the Gezi Park protests resounded in the slogans of the Pride March: 'Yesterday we were at Gezi, today we are here.' 'We exist too (biz de variz)!' These slogans expressed the agony of fighting for 'presence' and 'existence' - or more precisely for the politicization of these terms - especially for those constantly positioned at the crossroads of life and death. 'We exist too' was an echo of the everyday struggle to 'still exist' in the face of the state's 'cleansing operations' against trans people in the 1990s, as well as in 2013. 'We exist too' also signified the long fight against legal persecution in the face of numerous court cases aiming to ban LGBT organizations. It was also a reminder of the fact that since 2002, sixty-nine trans people had been murdered, their deaths otherwise minimized by comments from the former minister for Women and Family Affairs, who had declared gay people 'sick' and homosexuality a biological disorder requiring treatment. ${ }^{1}$

In other words, 'We exist too' did not signify here a privilege ascribed by the aggregate logic of identity politics ${ }^{2}$ and debates on the 'hierarchy of oppression'3 but rather spoke to the long history and everyday experience of living under the aporia of survival. Likewise, the slogan 'Yesterday we were at Gezi, today we are here' alluded to the fight for an agonistic and political presence at and beyond the Gezi protests, as has been argued poignantly by Emrah Yildiz. ${ }^{4}$ As a nighttime cruising ground for transwomen and gay men, Gezi Park welcomed those whose lifestyles did not fit neatly within the glamorous and cosmopolitan clubs of nearby Taksim Square and Istiklal Street. It occasionally hosted political gatherings (such as feminist protests on Women's Day) but was also haunted by its history of having been constructed upon an Armenian cemetery, the tombstones used as marble steps to enter the park. In this sense, Gezi Park was bearing witness to what it means to have to both defy and sustain the effects of ethnic and queer violence, social persecution, policing operations, and ferocious gentrification. Thus, the soil there was already fertile ground for further 
encounters between diverse crowds who were protesting the plans of the AKP (Adalet ve Kalkinma Partisi [Justice and Development Party]) for urban gentrification and 'cleansing operations'. In the midst of such political developments and in fear of another severe police intervention, the Pride March of 2013 was indeed an amazing event, as Ali commented.

Ali had been diagnosed with cancer a year earlier. A few days after the Pride March, he went back to the hospital, where he stayed until the devastating news of his death reached all of his friends and comrades. At the hospital, the slogan 'Yesterday we were at Gezi, today we are here' materialized differently. In this article, I will focus on the story of Ali, a transgender activist friend, who was fighting against transphobia, his illness, and eventual death - all during the 2013 public uprisings in Istanbul. Focusing on both the historic moment and this personal story, I ask: what happens when bodies assemble to protest, resist, and lay claim to an-other vision of liveable death, as well as life? More than that, how can one write about what haunts the public sphere if one first needs to trouble assumptions about what dies in death and what might need to survive life? It is the fact that we are already implicated in each other's lives and deaths, as I will explain, that drives me to linger on the desire for existence and hence to situate these questions as aporias of political struggles. Therefore, I also ask: how is the desire for existence implicated in the experience of identity as wound? Under what conditions does the demand for desire appear to confront the repetition of trauma? Or else, what echoes in the last breath of someone dying? After all, as I would like to argue, the language of the wound is political, and the aporia of survival is related to the desire for existence in life but also in/after death. However, this desire, rather than a form of 'cruel optimism, ${ }^{5}$ becomes in this case a performative claim of resistance and justice against neoliberal, heteronormative, phallogocentric, and sexist representations of possession and belonging.

\section{ON SURVIVAL}

I spent a month in a small room on the third floor with limited air; sleeping, feeling suffocated, but I did not lose my mind. My friends did their best to make the room look like my room at home and to find distractions to help me pass the time. 
Ali wrote this on 4 September $2013 .{ }^{6}$ He was going through one more chemotherapy treatment in a series of attempts to fight the cancerous cells that had been found in his body a year before. Ali had been diagnosed after his breast removal operation - an operation that had led him to visit a gynaecologist for the first time at the age of thirty-nine. Why? Because, as Ali explained in his blog, the fear of facing transphobia had made him avoid getting a check-up. ${ }^{7}$ Or as another trans friend commented later in a personal communication, 'The disease of cancer is now becoming like AIDS for trans people. No one wants to go to the doctor.' Indeed, a bodily wound or a bodily trauma, as one can think of cancer, becomes even more unbearable when one has first to bear the history of persecution against sexuality and desire. Or, how differently can one think of what it means to bear a 'wound' here?

For the literary theorist Cathy Caruth, trauma, coming from the Greek word for wound, referred originally to an injury inflicted on a body, while in its later use, following Freud and in particular the medical and psychiatric literature, the term trauma can be understood as a wound inflicted not upon the body but upon the mind. ${ }^{8}$ However, as Caruth poetically argues:

Trauma seems to be much more than a pathology or the simple illness of a wounded psyche: it is always the story of a wound that cries out, that addresses us in the attempt to tell us of a reality or truth that is not otherwise available. ${ }^{9}$

But contrary to an argument that understands the wound of the body as a simple and healable event and the wound of the mind as sudden and unexpected - which is nevertheless unconscious and hence never fully realized but experienced in latency or in the nightmares and repetitive actions of the survivors ${ }^{10}$ — in a case such as Ali's we cannot think of the body apart from the psyche. Here, the 'wound', rather than a repressed event that cries out, is a process bound up with the aporia of how to make its unrepresentability politically sound.

As a founding member of the Voltrans Transmen Initiative ${ }^{11}$ and with long experience in the LGBT and feminist movements, Ali was struggling to stay alive in the hospital. The notion of survival as a political praxis reverberated in each of his blog posts, where he was writing about his bodily transformations, his coming-out to his father, his life in the hospital as a trans man, the importance of having friends - or 'family conditioned by love and not by blood', as he put it. Indeed, the 
Gezi Park resistance coincided with Ali's resistance - his struggle to survive - and the LGBT community persistently participated in both, standing by his side through every step, taking care of him. But it was not only the intensity of the bodily pain that had to be taken care of at the hospital. As Ali wrote before he died, one needed to acquire special skills to give the nurses and the doctors of the hospital a 'trans manners 101 course'. Ali's 'family' — his lifelong comrades — were there to take care of that too. He wrote:

Even though it was because of [my friends'] warnings and interventions [that people's attitudes in the hospital changed], the fact that everybody in the hospital called me Ali made me feel safe. Furthermore, though hospital employees would see everything while taking care of me, including my genitals, it was pleasing to see their perceptions of my gender identity (as female) transforming. Because this meant that people accepted my gender identity (as male). In other words, it was a palpable indication of people's acceptance of the fact that I am a transsexual, a transgender and a trans man. ${ }^{12}$

The spirit of Gezi had entered the atmosphere of Ali's room at a time when many outside were feeling suffocated. Not being able to breathe because of tear gas was just a daily routine outside in Istanbul. But it was not only tear gas and the fear of unpredictable sovereign state power that were depriving people of the chance to breathe. Eight people died, at least four as a result of police violence; about 8,000 were injured, 104 sustaining serious head injuries and eleven people losing at least an eye, most as a result of plastic bullets fired by the police. And no one could really predict how many more people would be injured or killed, or for that matter, how many people had already been affected by post-traumatic stress disorder (PTSD), as Yasemin, an LGBT activist and psychologist explained to me and to another friend who was describing the transphobic street assault he had experienced a few days earlier in a street next to Gezi Park. The assault occurred because he is a cross-dresser, and it almost cost him his life. And just a few days before, the announcement that a transwoman had been found dead in her apartment had already spread the affects of sadness, mourning, despair, and anger among those who were directly or indirectly close to her.

'Every death of a transgender woman is a political murder.' This slogan was usually uttered in the streets or scrawled as graffiti on the 
city's buildings. Its sentiment also vibrated in Burçin's voice, who is another LGBT activist, after he attended the murdered transwoman's funeral in a city outside Istanbul. 'She was buried as a man because of the family pressure. We couldn't do anything. They cut off her breasts, dressed her in male clothes and kept the name given to her by birth, a male name', as he told me in a personal discussion. They erased her existence as a woman, they erased who she was, as they try to erase our existence too, daily, either slowly or more aggressively, I heard him saying in these words. And I wonder: is the desire for existence an unhealed and hence ongoing confrontation with a kind of death that cannot even be registered as a cry of loss?

No matter how many more deaths one can add to the list - and this is the invaluable work of those recording every single 'hate crime' in order for them not to be surrendered to the lure of forgetfulness still, people who die are not statistics. As another trans friend told me in anger, 'We are people who become statistics. You hear, "In the last weeks a third trans person died by being stabbed in the body 5-6 times." It is as if we are only bodies, as if we are not people, as if we don't have an identity.'

\section{DYING}

'Is the trauma the encounter with death, or the ongoing experience of having survived it?"13 Caruth has asked this question in relation to what she defines as the 'enigma of survival', especially as the realization that we are always already implicated in each other's traumas is inscribed in the 'endless testimony to the impossibility of living' ${ }^{14}$ In other words, for Caruth, 'What returns in the flashback is not the incomprehensibility of one's near death but the very incomprehensibility of one's own survival. ${ }^{, 15}$ And yet as has been rightly argued by Ann Cvetkovich, the 'wound' or the 'trauma' cannot be universalized, as it has to speak back to the affective historicity of the collective experience that has defined it. $^{16}$

On the night of 25 September 2013, we lost a comrade and friend, as well as Ali's beautiful energy and smile. But hope did not die with Ali. The funeral, which took place soon after his death, was crowded with people who made sure that 'Ali' would not die in his death, that the funeral procedures would be done according to his self-defined gen- 
der identity (and not the one assigned him by birth). On the gravestone, his name stayed Ali Arrkan, and the pink card (given to women) that was initially attached to his coffin was changed to blue (given to men). Colours here not only register the limits set between the gender binaries and gender troubles but also reflect the limits of bearing witness while facing the 'enigma of survival'. In this sense, what is at stake here is not just our inability to comprehend our own survival, as Caruth has argued, but also the very incomprehensibility of desiring to exist in death, or of desiring a liveable death, as I will now explain.

During the funeral, Ali's 'family chosen by love' finally convinced those employed to manage life's last rites of passage to let them wash his body and carry him all the way to the soil, something that is not typically permitted by religious institutions. Indeed, his family - the LGBT community - persistently tried to make sure his death would not change what he had fought for in life. Put simply, Ali's 'family' made it possible for him to claim, 'I am going to die as myself.' The referential force of this statement bears witness to the ambiguous connection between death and life: 'I am going to die' means ' $\mathrm{I}$ ' is dying, and 'I am going to die as myself' means 'I' survives (in) life. How? Let's linger for a moment on this double bind. Let's actually think of what it means to die in a name one has not been born to.

Birth already involves death because birth is the primary pivot point at which a gendered code is laid upon an infant (and another taken away) in order for the infant to be included in social life. The form of interpellation that accompanies the doctor's announcement 'It's a girl/boy' is one of the primary traumas of life, as it possesses and defines the meaning of the naked body by projecting upon it the historicity of persecution that haunts those not fitting in heterosexuality. As Judith Butler has argued, in the announcement that this is a 'girl', a form of 'girling' occurs to an infant who is "compelled to "cite" the norm in order to qualify and remain a viable subject'. ${ }^{17}$ In this sense, femininity, as well as masculinity, is not a choice but rather 'the forcible citation of a norm, one whose complex historicity is indissociable from relations of discipline, regulation, punishment', and hence it polices the limits set on other claims of existence and desire. ${ }^{18}$

Dying with a name you have not been born to, then, might indeed speak of a trauma that has been paradoxically erased. To die with a name one has not been born to is a performative re-enactment of the history of trauma to which one cannot bear witness. Let me explain 
this. Ali does not exist (as Ali) in the official records. Like many other transmen who resist state intrusion into their bodies, he never went through the process of official gender reassignment, which entails many years of psychoanalytic treatment, hormone therapy, and enforced surgical operations. The performativity of renaming oneself according to a desirable identity rather than maintaining that ascribed to one's self at birth is an act of resisting medical intrusion into one's body, and by doing so, it also resists intelligibility. Thus, 'Ali' is a name that does not exist, and by not existing, it troubles and re-politicizes the claim over an existence that resists translation into a simple narrative. Indeed, by making his story history, he is also erasing it. Put simply, the name inscribed on the tombstone, 'Ali', is not an 'I' that accedes to a fuller subjectivity but rather becomes an aporia of de-subjectivation; this name reflects the aporia of how to go back and tell the story of an 'I' that could never claim the terms of Ali's own existence. In the end, this process compels us to return to the memory of a wound so as to depart again and hence to historicize the relation between existence, desire, and loss.

De-constituting the ' $\mathrm{I}$ ' in this sense is an attempt neither to reconfigure its parts nor to perceive once again life as dismantled, but to speak of a loss that no familiar language can yet describe. The spectrality of this ' $\mathrm{I}$ ' troubles and re-politicizes, then, the very notion of haunting because it lays claims to its own differing and deferral (what Jacques Derrida coined 'différance') ${ }^{19}$ from the constitution of a proper name, or of a 'self'-acclaimed existence, especially when the claim to existence is also a performative assertion of loss and death because someone who does not exist dies. Paradoxically, death comes to affirm someone's life, a life that has not been publicly recognized.

Thus, Ali's claim that 'I am going to die as myself' is a claim of loss, a process of expropriating or dispossessing the positionality or fixed position assigned to someone by birth and re-ascribed to that person by death. Claiming this loss opens the way to experience, narrate, and politicize mourning. Rather than rendering oneself to the unresolved effects of melancholia, this process provides the means by which one can confront trauma, as it also opens the way to translate pain into a language that continues to criticize the normative terms of signifying existence. In this sense, being dispossessed by death is a process defined by the ambivalent relationship of 'letting go' (of a fixed subject position) and 'holding on' (to the possibility of asserting life). In other 
words, it is a process defined by loss as well as by the excess of desiring to be present, to 'exist'.

But how easy is it to publicly seek this form of dispossession, this politicization of existence, when some people's experiences are erased from the social memory of a society that keeps reproducing statistics of death and engaging in other forms of social killing? In what ways can one secure 'space' for death and mourning, for public presence and desire? To answer these questions one first needs to understand how the political geography of space is always implicated in the embodied biographies of those whose desires do not appear to belong in the architectural aesthetics of the cities they inhabit. In this sense, Ali's loss and trauma cannot be seen separately from that of his city, which is built upon neoliberal structures of governance and cosmopolitan aesthetics, and defined by severe policing and local histories of ethnic and gender violence.

\section{MEMORY}

According to Kathleen Stewart, space carries 'haunting signs' — signs that upset the aura of a city after a certain form of ruination has occurred. ${ }^{20}$ The name 'Ali', written on a tombstone like those tombstones of the Armenian cemetery leading into Gezi Park, carries meanings that become 'haunting signs' because they reverberate with the materiality of a trauma that keeps demanding presence, even if displaced and exiled from its public and legal recognition as such. The marks of life built in the marks of death in this case act first of all as reminders of the recent deaths of gay and transgender people, as well as of the 'cleansing operations' of the 1990s, when the project of gentrification in Istanbul first embarked upon an attack of trans people and stray dogs alike.

That period is often recalled in horror, as in the words of a transwoman and sex worker, Tulay, who was interviewed by Deniz Kandiyoti: 'Tulay describes a military-style operation, the police using fire-ladders to break into flats through the windows, with triggers cocked; a first-floor flat was set on fire. "They behaved as though they were expecting to meet with armed resistance," she comments. ${ }^{21}$ Especially in the summer of 1996, when the UN Habitat II conference was hosted in Istanbul, the 'cleansing operation' targeted stray dogs and trans peo- 
ple. At that time, Süleyman Ulusoy, the chief of the Beyolu Police Department in 1991, was brought back into his post after alleged complaints by local inhabitants against trans people and transvestites. Süleyman Ulusoy was also known by the nickname Süleyman the Hose (Hortum Süleyman) because his favourite torture technique was beating suspects at the head with plastic hose pipes.

These 'cleansing operations', which started by targeting the redlight districts of Beyolu, were a result of national, political, and economic transformations during a period when Istanbul was surrendering to the type of urban gentrification that renders cities 'aestheticized commodities', all in order to make them attractive to foreign capital and marketable for a global audience. ${ }^{22}$ At the same time, during that period widespread fear took over public opinion when Tayyip Erdoğan won the local elections on 27 March 1994 as a candidate of the Islamic Welfare Party. Back then, as the anthropologist Yael Navaro-Yashin has written, 'tales of nightmare' spread around the city, a discursive mosaic of black humour and rumours of a new conquest. ${ }^{23}$ The fears of secularists were heightened by Erdoğan's description of his own victory as 'the second taking of Istanbul, in the sense of bringing light into darkness'. ${ }^{24}$ Through this statement and his later announcements that his first priority would be to build a mosque and an Islamic cultural centre in Taksim, Erdoğan was defining the parameters of a 'new project': reclaiming Istanbul from earlier visions of a secular, Western, and modern republic and trying to reinject into the city the old aura of the Islamic Ottoman Empire heritage. This was immediately taken as proof that a new era had begun in which Atatürk's Westernized reforms would suffer a final deathblow.

However, in the end, as Ayşe Öncü has argued, the strategy of imprinting Islamic consciousness onto the urban topography of Istanbul did not need to rely on the metaphor of conquest 'in part because the Islamic movement has been transformed into a neo-liberal, religious-nationalist establishment'; instead of conquest, the new discourse focused on claims of 'creating alternative times and spaces where the unity and harmony of Islam can be imagined and lived in the fabric of the city'. ${ }^{25}$ Erdoan's pre-election rhetoric had mainly favoured the periphery and the shanty neighbourhoods, not the cosmopolitan centre of Beyolu, making him appear as a protector of the 'people' rather than as someone who would surrender to the needs of the type of economy that a global city entails. ${ }^{26}$ However, soon after his election, it became 
evident that the global city project was first on Erdoğan's agenda when he started investing in high technology and heavy industry. ${ }^{27}$

Susan Buck-Morss has remarked that 'technologies of oppression' must first 'clean' the streets of prostitutes and vagrants, stripping from sight presences that would threaten the rhythm of economic growth and vacating from the public sphere any 'aura' of passion that would unsettle and undermine their projects. ${ }^{28}$ Following her insightful remarks, I would like to argue that there is indeed a silencing effect when cities are forced to appear clean of potentially 'dangerous' bodies, and latent social trauma is the outgrowth of the repression of voices that may raise political dissent. ${ }^{29}$ In other words, the effects of the intense gentrification project in Istanbul were reflected not only in political violence (including cleansing operations as well as regular policing of the streets and military-style attacks of protesters, etc.) but also in the promulgation of a fantasy of benign 'co-existence in our differences'. In this sense, the ghostly atmosphere of trauma, as well as the inability to deal with it, did not only haunt the terrifying use of violence against the Gezi protesters but also cast a spectral shadow over the project to transform Istanbul into 'a timeless moment that brings together a constellation of elements - a mixture of intellectual freedoms, political emancipation, economic vitality, and cultural creativity — and ties them with the present through the idea of multiculturalism'. ${ }^{30}$ This vision has sought to encompass 'all that is blended - from Sufi electronica (cutting-edge beats laced with Sufi Islamic mysticism) to trendy nightclubs where the young and the beautiful rise spontaneously from their tables and perform a horon (a Black Sea line dance)', as Öncü writes. ${ }^{31}$ Some of this can be found around Taksim, down Istiklal, and around Beyoğlu, that is to say in spaces where such 'politics of memory' challenge the possibility both of representing and of responding to trauma, especially when the 'noise' of multiculturalism serves as a technology that silences political dissidence.

It is exactly this visualisation and representation of trauma and its simultaneous displacement that become haunting, as it makes us confront the aporia of survival. The term 'haunting', according to Avery Gordon, comes to mean 'an animated state in which a repressed or unresolved social violence is making itself known, sometimes very directly, sometimes more obliquely'. ${ }^{32}$ For Gordon, such moments raise questions about what feels uncanny, what signals presence in time, what interferes with repressed material, and what escapes containment 
and repression. More importantly, though, for Gordon, the ghost that haunts is not 'some ineffable excess' but is very much present and visible and hence demands attention. ${ }^{33}$ At the same time, however, being haunted by the desire for memory cannot only reveal what has been repressed but also represses again by returning and repeating a past that has been erased. ${ }^{34}$ In other words, 'haunting signs' demonstrate a refusal to mourn the death of a testimony that is imprinted in the social and political melancholia that trespasses on not only the materiality of life but also the atmosphere of a city whose life and survival are based upon a multitude of deaths. This melancholic atmosphere intensifies the need to fight for the space to remember what has been erased from social memory, and it intensifies the desire to live a life that can be mourned on one's own terms.

The tombstones of trans people who are denied the right to be buried in their own name and of gays and lesbians who do not lie next to their own kin because their families are not socially recognized - these tombstones become signs that haunt the structures of a fantasy that the body politic is built upon national, social, and religious homogeneity. Is it that this body politic forgets to remember? Or is it because it cannot forget to remember but rather disregards memory and thus manages to silence it, to envelop it indifferently in everyday life and hence to repress it and to kill it twice?

This double death of memory happens simultaneously (and in paradoxical ways) even if someone might want to pose the demand of desiring more memory. The paradox accompanying memory is that it can be erased precisely as it is inscribed as such. Does our confrontation with the cruelty of the 'past-present' end when we find access to the space of national narration and when memorialisation becomes a priority? Can we really not forget that a tombstone is not only a monument of memory but also a sign of amnesia when confronting the current political scene, which continues to produce multiple injuries, death, and war? In this sense, the desire for memory that also accompanies the desire for existence (in life or after death) might entail attributing responsibility and hence might even lead to coming to terms with the past, and this cannot but be an important and progressive claim. At the same time, though, we should not forget that facing the past is always suspended, and its representation becomes even more difficult, almost impossible, while confronting the repetition of trauma. 
For Caruth, the history of trauma helps us to understand that history, rather than being referential or based on the narration of truth as fact, begins when immediate understanding is impossible. ${ }^{35}$ Trauma is inaccessible, as it cannot be declared, represented, affirmed, or contested; it cannot be possessed by consciousness and yet possesses life and manifests itself in latency. Thus, Caruth has proposed: 'The historical power of the trauma is not just that the experience is repeated after its forgetting, but that it is only in and through its inherent forgetting that it is first experienced at all. ${ }^{36}$ And the crying voice echoing this 'unclaimed experience' demands not only to be heard but also a response.

But what kind of responses can be given here? Lauren Berlant has rightly argued that there is a risk attached to political responses to trauma. The climate of chaos, crisis, and injustice that surrounds us prompts us to desire 'alternative filters that produce the sense - if not the scene - of a more liveable and intimate sociality', and this is but another name for the desire for the political - a political that appears as 'cruel optimism' when 'despite an awareness that the normative political sphere appears as a shrunken, broken, or distant place of activity among elites, members of the body politic return periodically to its recommitment ceremonies and scenes'. ${ }^{37}$ For Berlant, this not only confirms attachment to the system but also validates the system itself, 'even if the manifest content of the binding has the negative force of cynicism or the dark attenuation of political depression'. ${ }^{38}$ Thus, one might need to ask what is entailed in recruiting words to talk about and hence represent death or genocide, the terror and fear of everyday persecution and war, the experience of racism, homophobia, transphobia, and hate crimes - that is, to represent experiences that are non-representable. As such, they invite and challenge us to represent them, which runs the unavoidable risk of turning trauma into a desire for a (new and more powerful) political identity, instead of letting them remind us that it is identity itself that is a wound.

At the embodied fringes of modern thanatopolitics, more and more identities are becoming targets. Such identities include 'migrant', 'refugee', 'homosexual', 'disabled', etc., and they are constructed as offensive, dirty, ill - worthy of a death that silences the memory of a (past-present) mourning. Thus, the aporia of death accompanies us not only because we wonder about the when, where, and how of our own death only. By reflecting the intersubjective relation that corresponds to 
the experience of trauma and by embodying the 'glaring absence' of those who also structure our public life, ${ }^{39}$ the aporia of death echoes the need to understand that 'the body is a memory come alive', to use the words of Athena Athanasiou and Judith Butler. The body 'persists, survives, showing and enacting a social history, memorializing those forms of suffering and loss against the lure of forgetfulness.. ${ }^{40}$ So many people die every day while figuring as numbers and statistics that continue to mark the body politic of a society that forgets to remember even when - or especially when — it remembers. Memory is impossible in this sense, and the desire for memory has a disquieting effect as the sound of a wound that cries out, testifying to the numbers of those dying.

It is in this sense that Ali's name, imprinted either on the tombstone or on our hearts, remains in language as a demand — to claim, to trouble, and to politicize mourning. Likewise the names of so many others who are commemorated in the protests and press releases of LGBT groups that continue to demand a public presence, despite facing social persecution and, more than that, amnesia. These names continue to exist in our hearts and memory, while upsetting the very terms that structure our language and while bringing questions of representation into crisis. Such representation trouble, as Butler explains, is connected not to those who are turned into special or exceptional cases but to those who become a 'figure of politics'. ${ }^{41}$ That is, it refers 'not to politics as a question of representation but to that political possibility that emerges when the limits to representation and representability are exposed'. ${ }^{42}$ The common anger that was shared between all those who gathered in 2013 at Gezi Park to resist gentrification plans, despite their often painful differences, emerged as a result of multiple and complicated historical, social, and political processes. It reverberated across a mutual need to 'exist' (in the language of another politics) despite the silencing effects of the political management of life and death.

\section{V. 'BEING' - IN SOLIDARITY}

After Ali gave his last breath, the collective mourning of those who came to his funeral transmitted the following demanding, if not unanswered, questions: How does the right to life return as a matter of survival and what constitutes a liveable life? But even more, it was posing 
the question of how we should understand the desire to exist as (a demand for) a liveable death. Ultimately, the 'we' uttered in the streets, as well as the 'we' conveyed in the corpus of Ali's funeral, offers a continuous exercise in how not to let the self surrender to the lure of forgetfulness and how to insist on resisting the dangers of normalization. For example, the slogan 'We exist too' - which 'translates [a] collective bodily presence [and] might be re-read as "We are still here", meaning 'We have not yet been disposed of. We have not slipped quietly into the shadows of public life,' as Butler argues ${ }^{43}$ - becomes evidence of the ways that solidarity is 'an injurious yet enabling mode of "concerted action" in conditions of dispossession' as Athanasiou emphasizes. ${ }^{44}$

When one is 'girled' at birth but demands to live and continue living, after death, as Ali, or when one cannot live the life and death one wills, this will - a will to life, a will to survival — is politically bound up with and affectively transmitted through a desire to keep troubling the fantasy of a 'good life'. Hence it also repoliticizes the liberal acclamation of identitarian politics by insisting on returning to what Sara Ahmed has coined 'the histories that hurt'. ${ }^{45}$ This entails an engagement with the labour of the negative, which in this case means enquiring, in Butler's terms, 'how the problem of desire suffuses the issue of the name'. ${ }^{46}$ This question leads us in turn to think anew of the act of survival, to critically engage with the haunting experience of a wound as it pertains to bodily actions and redefines the 'shadowy realms' of body politics. And this cannot result in a simple affirmation of life: a 'liveable death' does not just come to 'rescue' the subject. Rather, posing this question means that one refuses to deny that death might twice kill certain 'unliveable lives'.

By understanding the 'wound' in its negative reverberations, my aim is to trouble the meaning attributed to survival as reparative, restorative, recuperative, and healing of normative lives (lifestyles). Put differently, survival, rather than a form of 'cruel optimism', becomes a performative claim against the perils of intelligibility, against the dangers of translating collective resistance into digestible notions, dreams, and fantasies of belonging. The insistence, then, on desiring to be present, rather than demanding a rescue for an excluded identity or fantasy of integration or 'good' life (or a 'better' death), might carry within it the rhythm of a political passion that claims forms of mourning and loss that haunt meaning as they oppose the institutional and linguistic registers upon which the wounded body or the wound of death gets to 
be decoded and 'fixed' back to its proper place of meaning; it might carry within it the desire to let such negative passions hurt in return the already wounded body (politic) and injure those processes that permit the radical annihilation of the desire to live and die differently.

To conclude, in the context of Gezi Park, Ali's death gives life to the aporia of what it means to live and die otherwise. How can one's passionate attachment to a different vision of life/death be made to survive the constitution and management of violent annihilation, neoliberal governmentality, and modern biopolitics or, for that matter, thanatopolitics, especially if one's life/death has been constituted as prohibited and invisible? In the context of Ali's life, Gezi Park is a reminder of the sacrifices entailed in opposing the neoliberal, nationalist, sexist, homophobic, and transphobic regimes that sustain and reproduce uncertainty, fear, social deprivation, and violent dispossession. In reality, it is not death that renders us dispossessed. Rather, it is an inability to voice a persistent claim against the conditions that kill us in death that kills (desire in) life. How can one make this claim survive?

\section{NOTES}

1 Eirini Avramopoulou, 'Signing Dissent in the Name of "Woman": Reflections on Female Activist Coalitions in Istanbul, Turkey', in Migration, Gender, and Precarious Subjectivities in Times of Crisis, ed. by Athena Athanasiou and Giorgos Tsimouris, Special Issue of The Greek Review of Social Research, 140-41, B'-Г', (2013), pp. 233-46.

2 As, for example, when the proliferation of accounts of 'who is who' and 'how one will be seen', or the genders and their endless division in acts (such as queer, dyke, femme, butch, FTM, MTF, transgender, intersexed and so on) define claims of existence and identity-belonging.

3 Sarah F. Green, Urban Amazons: Lesbian Feminism and Beyond in the Gender, Sexuality, and Identity Battles of London (New York: St. Martin's Press, 1997), p. 131. Green has insightfully coined the term 'hierarchy of oppressions' to denote the 'level of stigma experienced' within the LGBT community through symbolic competitions over different experiences of oppressions defined by colour, class, gender etc. For an analysis and a critique of identity politics in the LGBT activist community, see also Kath Weston, Render Me, Gender Me: Lesbians Talk Sex, Class, Color, Nation, Studmuffins (New York: Columbia University Press, 1996); and Kath Weston, Gender in Real Time: Power and Transience in a Visual Age (New York: Routledge, 2002).

4 Emrah Yildiz, 'Sexuality and Solidarity after Gezi', Counterpunch, 12 July 2013, <http://www.counterpunch.org/2013/07/12/sexuality-and-solidarity-after-gezi> [accessed 19 January 2016]. 
5 Lauren Berlant, Cruel Optimism (Durham, NC: Duke University Press, 2011).

6 Ali Ankan, 'The Hospital's Exam on Trans', Kaos GL Magazine, 27 September 2013, <http://kaosgl.org/page.php?id=14897> [accessed 19 January 2016].

7 See Ali's blog (in Turkish), <http://hikayeci.livejournal.com> [accessed 19 January 2016].

8 Cathy Caruth, Unclaimed Experience: Trauma, Narrative and History (Baltimore and London: Johns Hopkins University Press, 1996), p. 3.

9 Ibid., p. 4.

10 Ibid., pp. 3-4. Caruth elaborates this argument while referring to the story told by Tasso in his romantic epic Gerusalemme Liberata, in which Tancred kills his beloved without knowing that she is dressed as an enemy knight. After this tragedy, 'He slashes with his sword at a tall tree; but blood streams from the cut and the voice of Clorida (his beloved), whose soul is imprisoned in the tree, is heard complaining that he has wounded his beloved once again.' Ibid., p. 2.

11 <http://vol-trans.blogspot.de/> [accessed 25 April 2016].

12 Ankan, 'The Hospital's Exam on Trans'.

13 Caruth, p. 7.

14 Ibid., pp. 61-62.

15 Ibid., p. 64.

16 Ann Cvetkovich, An Archive of Feelings: Trauma, Sexuality, and Lesbian Public Cultures (Durham, NC: Duke University Press, 2003), p. 19.

17 Judith Butler, Bodies that Matter: On the Discursive Limits of 'Sex' (New York: Routledge, 1993), p. 232.

18 Ibid.

19 Jacques Derrida, 'The Battle of Proper Names', in The Derrida Reader: Writing Performances, ed. by Julian Wolfreys (Edinburgh: Edinburgh University Press, 1998), pp. 74-87. Actually, in Derrida's inscription of the notion 'proper name', the paradox reminds us that when singularity is diffused by 'différance', there is nothing that can be properly named. Instead, the invocation of a name appears to stabilise the 'proper' in utterance and exposes the heterologic within it. See also Peggy Kamuf, 'Introduction: Reading between the Blinds', in A Derrida Reader: Between the Blinds, ed. by Peggy Kamuf (Hemel Hempstead: Harvester Wheatsheaf, 1991), pp. xiii-xlii (p. xxviii).

20 See Kathleen Stewart, A Space on the Side of the Road: Cultural Poetics in an 'Other' America (Princeton: Princeton University Press, 1996), p. 96.

21 Deniz Kandiyoti, 'Pink Card Blues: Trouble and Strife at the Crossroads of Gender', in Fragments of Culture: The Everyday of Modern Turkey, ed. by Deniz Kandiyoti and Ayşe Saktanber (London: I.B. Tauris, 2002), pp. 277-93 (p. 287).

22 Ayfer Bartu Candan and Biray Kolluolu, 'Emerging Spaces of Neoliberalism: A Gated Town and a Public Housing Project in Istanbul', New Perspectives on Turkey, 39 (2008), pp. 5-46 (p. 13).

23 Yael Navaro-Yashin, 'The Historical Construction of Local Culture: Gender and Identity in the Politics of Secularism versus Islam', in Istanbul: Between the Glo- 
bal and the Local, ed. by Çaglar Keyder (Lanham, MD: Rowman \& Littlefield, 1999), pp. 59-76 (pp. 63-67).

24 Hürriyet, 26 December 1993, cited in Tanıl Bora, 'Istanbul of the Conqueror: The "Alternative Global City” Dreams of Political Islam', in Istanbul, ed. by Keyder, pp. 47-58 (p. 48).

25 Ayșe Öncü, 'Narratives of Istanbul's Ottoman Heritage', in Spatial Conceptions of the Nation: Modernizing Geographies in Greece and Turkey, ed. by Nikiforos Diamandouros, Thalia Dragonas, and Çaglar Keyder (New York: I.B. Tauris, 2010), pp. 205-28 (p. 217).

26 Bora, p. 54.

27 Ibid., p. 56.

28 Susan Buck-Morss, 'The Flaneur, the Sandwichman and the Whore: The Politics of Loitering', New German Critique, 39 (1986), pp. 99-140 (p. 136).

29 See also Neni Panourgia, Dangerous Citizens: The Greek Left and the Terror of the State (New York: Fordham University Press, 2009).

30 Öncü, pp. 211 and 213.

31 Ibid.

32 Avery Gordon, Ghostly Matters: Haunting and the Sociological Imagination (Minneapolis: University of Minnesota Press, 2008), p. xvi.

33 Ibid.

34 See Caruth.

35 Ibid., p. 182.

36 Ibid., p. 187.

37 Berlant, p. 227.

38 Ibid.

39 Athena Athanasiou and Judith Butler, Dispossession: The Performative in the Political (Cambridge: Polity Press, 2013) p. 196.

40 Ibid., 172.

41 Judith Butler, Antigone's Claim: Kinship between Life and Death (New York: Columbia University Press, 2000), p. 2.

42 Ibid.

43 Athanasiou and Butler, p. 196.

44 Ibid., p. 184.

45 Sara Ahmed, 'Multiculturalism and the Promise of Happiness', New Formations, 63 (2008), pp. 121-37 (p. 135).

46 Athanasiou and Butler, p. 137; see also Butler, Antigone's Claim. 
Eirini Avramopoulou, 'Claims of Existence between Biopolitics and Thanatopolitics', in De/Constituting Wholes: Towards Partiality Without Parts, ed. by Christoph F. E. Holzhey and Manuele Gragnolati, Cultural Inquiry, 11 (Vienna: Turia + Kant, 2017), pp. 67-84 <https://doi.org/10.37050/ci-11_04>

\section{REFERENCES}

Ahmed, Sara, 'Multiculturalism and the Promise of Happiness', New Formations, 63 (2008), pp. 121-37

Ankan, Ali, ‘The Hospital's Exam on Trans', Kaos GL Magazine, 27 September 2013, <http: / /kaosgl. org/page.php?id=14897> [accessed 19 January 2016]

Ankan, Ali, Blog (in Turkish), <http://hikayeci.livejournal.com> [accessed 19 January 2016]

Athanasiou, Athena and Judith Butler, Dispossession: The Performative in the Political (Cambridge: Polity Press, 2013)

Avramopoulou, Eirini, 'Signing Dissent in the Name of "Woman": Reflections on Female Activist Coalitions in Istanbul, Turkey', in Migration, Gender, and Precarious Subjectivities in Times of Crisis, ed. by Athena Athanasiou and Giorgos Tsimouris, Special Issue of The Greek Review of Social Research, 140-41, B'-Г', (2013), pp. 233-46 <https://doi.org/10. 12681/grsr.67>

Berlant, Lauren, Cruel Optimism (Durham, NC: Duke University Press, 2011) <https://doi.org/ $10.1215 / 9780822394716>$

Buck-Morss, Susan, 'The Flaneur, the Sandwichman and the Whore: The Politics of Loitering', New German Critique, 39 (1986), pp. 99-140 <https://doi.org/10.2307/488122>

Butler, Judith, Antigone's Claim: Kinship between Life and Death (New York: Columbia University Press, 2000)

Bodies that Matter: On the Discursive Limits of 'Sex' (New York: Routledge, 1993)

Candan, Ayfer Bartu and Biray Kolluoğlu, 'Emerging Spaces of Neoliberalism: A Gated Town and a Public Housing Project in Istanbul', New Perspectives on Turkey, 39 (2008), pp. 5-46 $<$ https://doi.org/10.1017/S0896634600005057>

Caruth, Cathy, Unclaimed Experience: Trauma, Narrative and History (Baltimore and London: Johns Hopkins University Press, 1996)

Cvetkovich, Ann, An Archive of Feelings: Trauma, Sexuality, and Lesbian Public Cultures (Durham, NC: Duke University Press, 2003) <https://doi.org/10.1215/9780822384434>

Derrida, Jacques, 'The Battle of Proper Names', in The Derrida Reader: Writing Performances, ed. by Julian Wolfreys (Edinburgh: Edinburgh University Press, 1998), pp. 74-87

Gordon, Avery, Ghostly Matters: Haunting and the Sociological Imagination (Minneapolis: University of Minnesota Press, 2008)

Green, Sarah F., Urban Amazons: Lesbian Feminism and Beyond in the Gender, Sexuality, and Identity Battles of London (New York: St. Martin's Press, 1997)

Kamuf, Peggy, 'Introduction: Reading between the Blinds', in A Derrida Reader: Between the Blinds, ed. by Peggy Kamuf (Hemel Hempstead: Harvester Wheatsheaf, 1991), pp. xiii-xlii

Kandiyoti, Deniz, 'Pink Card Blues: Trouble and Strife at the Crossroads of Gender', in Fragments of Culture: The Everyday of Modern Turkey, ed. by Deniz Kandiyoti and Ayşe Saktanber (London: I.B. Tauris, 2002), pp. 277-93 
Navaro-Yashin, Yael, 'The Historical Construction of Local Culture: Gender and Identity in the Politics of Secularism versus Islam', in Istanbul: Between the Global and the Local, ed. by Çaglar Keyder (Lanham, MD: Rowman \& Littlefield, 1999), pp. 59-76

Panourgia, Neni, Dangerous Citizens: The Greek Left and the Terror of the State (New York: Fordham University Press, 2009) <https://doi.org/10.2307/j.ctt13x011k>

Stewart, Kathleen, A Space on the Side of the Road: Cultural Poetics in an 'Other' America (Princeton: Princeton University Press, 1996)

Voltrans, <http://vol-trans.blogspot.de/> [accessed 25 April 2016].

Weston, Kath, Gender in Real Time: Power and Transcience in a Visual Age (New York: Routledge, 2002)

_ Render Me, Gender Me: Lesbians Talk Sex, Class, Color, Nation, Studmuffins (New York: Columbia University Press, 1996)

Yildiz, Emrah, 'Sexuality and Solidarity after Gezi', Counterpunch, 12 July 2013, <http://www.counterpunch.org/2013/07/12/sexuality-and-solidarity-after-gezi> [accessed 19 January 2016]

Öncü, Ayşe, 'Narratives of Istanbul's Ottoman Heritage', in Spatial Conceptions of the Nation: Modernizing Geographies in Greece and Turkey, ed. by Nikiforos Diamandouros, Thalia Dragonas, and Çaglar Keyder (New York: I.B. Tauris, 2010), pp. 205-28 